\title{
The Role of the ESP Practitioner as Business English Teacher
}

\author{
Mounir Chibi
}

Faculty of Letters and Human Sciences

Ibn Tofail University, Kenitra, Morocco

\begin{abstract}
Teaching English for specific purposes (ESP) has always been an issue of concern in the field of English as a foreign language (EFL). Due to the increasing demands on ESP classes, especially in higher education, teachers of English for general purposes (EGP) have taken more of an interest in teaching ESP these days; nevertheless, many of them find it an uphill to teach such classes owing to the specificities of the discipline and the special teaching qualities it requires. This paper aims at highlighting some of the issues related to teaching ESP, basically the role of ESP practitioners as business English (BE) teachers. To achieve such a goals, the paper starts with some basic concepts of ESP, discusses BE as a branch of the ESP tree, and sheds light on the fundamental role of needs analysis (NA) in ESP and BE classes. Finally, the article concludes with highlighting the roles the ESP practitioners, particularly $B E$ teachers, are to carry out to ensure a conducive environment for successful ESP classes, especially in a business context.
\end{abstract}

Keywords-ESP, BE, EGP, needs analysis, ESP practitioners' roles, $B E$ teachers.

\section{INTRODUCTION}

It is needless to purport that the value of English as an international language goes unquestionable. English is the lingua franca of the world (Nelson, 2011; Kachru and Nelson, 2006) as well as the language of communication, science, economy, politics, business (M. Johns, 1991; Dudley-Evans and St. John, 1998). Specifications of learners' purposes for learning English have created a need for and given rise to English for specific purposes (ESP). Since its emergence in 1960's (Hutchinson and Waters, 1987), the demands for ESP courses have been growing rampantly. This is due to the ongoing economic and technological upheavals in a world where globalisation is the dominant facet of the twentyfirst century (Ennaji, 1997). In connection to this, ESP has inspired a lot of governments to embrace such a discipline in their national curricula. In this context, Morocco, among many other countries all over the world, integrated ESP within its curricula in higher institutes and universities (Ennaji, 1997).
To render ESP applicable and workable, pioneering figures of the stature of Mackay and Mountford (1978), Hutchinson and Waters (1987), Robinson (1991), Dudley-Evans and St. John (1998), and others have carried out a plethora of studies examining wide range of issues ESP has brought to the surface. Given such facts, investigating the teaching of ESP has been also the subject-matter of some Moroccan researchers such as Ouakrim (1997), Ennaji (1997), Bouzidi (2009), etc. To set the wheels in motion, they have tackled numerous issues as regards ESP to establish a theoretical and practical framework that enables Moroccan teachers of ESP in general and BE in particular to ensure effective teaching in ESP settings. Also, the aim is to prepare Moroccan students to operate effectively in their professional life and overcome the challenges of the third millennium. Nevertheless, the field is still fraught with problems or, in the broad sense, impediments that deter teachers from teaching ESP effectively. For instance, Ennaji (1997) found that teaching ESP in private higher institutes in Morocco is challenging and different from teaching English in public schools. He also contends that the fact that most teachers have no formal training in teaching ESP aggravates the problem. Ouakrim (1997) argues that factors such as the teachers' attitude towards teaching ESP, the complexity of ESP syllabi, and absence of enough practice context (institutes and schools) seem to pose more of a threat to teachers to practice and render ESP teaching more fruitful in Morocco .

\section{DEFINITION OF ESP}

Providing an accurate definition for ESP is a bit far-fetched, for theoreticians and experts in the field do not agree on a clear-cut definition of the term; divergent definitions have been given since ESP appeared (DudleyEvans and St. John, 1998). To begin with, Hutchinson and Waters (1987) consider ESP as an approach that seeks to match the learners' needs with the language taught in a particular learning context. As they put it, "tell me what you need English for, and I will tell you the English that you need" (p.8). For them, Hutchinson and Waters (1987), ESP is "an approach to language teaching, course design and materials development in which all decisions 
as to context and methods are based on the learners reasons for learning" (p. 19). Robinson (1991) defines ESP as a goal-directed approach based on needs analysis -the core of any ESP course development- that closely defines the objective for which students use English as a medium. Moreover, Robinson also states that a distinctive feature of ESP is the number of constraints, such as limited time of training and targeting adult learners in homogeneous classes according to their work or field of studies. Streven's (1988) definition of ESP provided four absolute characteristics and two variable ones. As far as the absolute characteristics are concerned, ESP

1- centered on the most relevant needs of the learner;

2- relevant in terms of themes, objectives, and activities;

3- necessary in that the language taught should be appropriate to those activities in lexis, syntax, discourse, and semantics;

4- somehow different from General English.

As for the variable characteristics, Streven (1988) defines them as follows:

1- ESP may only be related to particular skills to be learned.

2- may not follow any orthodox methodology set in advance.

As the aforementioned definitions contain strengths and weaknesses, Dudley-Evans and St. John (1998, pp. 4-5) modified Stevens' definition of ESP and came up with a broader and more detailed one. As for the absolute characteristics, Dudley-Evans and St. John posit that ESP a) is designed to meet specific needs of the learners, b) makes use of underlying methodology and activities of the discipline it serves, and c) is centered on the language (grammar, lexis, register), skills, discourse and genres appropriate to these activities. By the same token, instead of contenting themselves with only two variable characteristics, Dudley-Evans and St. John added the following variables:

1- ESP may be related to or designed for specific disciplines.

2- ESP may use, in specific teaching situations, a different methodology from that of general English.

3- ESP is likely to be designed for adult learners, either at a tertiary level institution or in a professional work situation. It could, however, be used for learners at a secondary school level.

4- ESP is generally designed for advanced students. Most ESP courses assume basic knowledge of the language system, but they can be taught to beginners.
In brief, the various definitions above show that ESP, notwithstanding its goals and directions, belongs to the field of general English language teaching (ELT), especially TEFL or TESL. ESP courses are goal-directed and aim at meeting learners' needs. ESP focuses on what learners need to do with English to operate successfully in a specific context. Therefore, ESP is a learner-centered approach to teaching English (Hutchinson and Waters, 1987). As regards the absolute characteristics, DudleyEvans and St. John (1998) share Hutchinson and Waters' (1987, p. 19) stance that "ESP is an approach to language teaching in which all decisions as to content and method are based on the learner's reason for learning". As for the variable characteristics, ESP meets the needs of learners and enables them to utilise English in their specific fields, such as science, technology, and business. Primarily, an ESP course targets adult learners with some knowledge of English; however, it can also be taught to beginners. An instance for this is business English.

\section{BUSINESS ENGLISH}

As a descendent of the ESP tree in general and of the branch of English for occupational purposes (EOP) in particular, business English (BE) or English for business purposes (EBP) has been announced the most evolving branch of ESP today. (Dudley-Evans and St John, 1998; Hutchinson and Waters, 1987). In addition, BE differs from other ESP branches as it is "a mix of specific content (relating to a particular job or industry), and general content (relating to general ability to communicate more effectively, albeit in a specific context)" (Ellis and Johnson, 1994, p.3).

Today, a large proportion of people use English in the business field (Frendo 2005). BE has grown to become the language of everyday international business communication, transactions, meetings and study days, to mention but a few instances. In this vein, Frendo (2005, p. 1) asserted that $\mathrm{BE}$ "uses the language of commerce, of finance, of industry, of providing goods and services". Consequently, BE becomes appealing to a nonfinite number of learners as it caters for their purpose (Ellis and Johnson, 1994). The growing awareness of the significance of BE today has resulted in an incomparable interest in the learning and teaching of this sub-branch of ESP. For teachers, BE is both a lucrative and a trendy language field that makes them distinguished (Dudley Evans and St. John, 1998). For students, learning BE is an opportunity to satisfy their 'work related needs' (Donna, 2000, p.3) and a shortcut towards a successful professional life (Dudley Evans and St. John, 1998). However, it is essential to mention that BE learners' needs vary according to who they are and what they need the language for. For instance, pre-experienced learners 
learn BE to secure a job while job-experienced learners have enough professional background and therefore have specific needs for which they learn BE (Frendo, 2005). Hence, it is crucial to differentiate between English for general business purposes (EGBP) and English for specific business purposes (ESBP).

\section{English for General Business Purposes (EGBP)}

EGBP refers to the courses for "pre-experience learners or those at the very early stages of their career" ( Dudley-Evans and St John, 1998, p. 55). EGBP courses provide a wide variety of English through business settings. The language activities are core EFL ones except vocabulary. To provide a further explanation, like English for general purposes (EGP), EGBP courses focus on developing the main four skills: speaking, listening comprehension, reading comprehension, and writing. The only difference is that they are set in a business context (Donna, 2000; Dudley-Evans and St John, 1998). Ellis and Johnson (1994) posit that three factors determine preexperience learners' purposes to learn EGBP. The first one is "the development of the reading and listening skills, with strong emphasis on the vocabulary of the subject" (p.6) to function adequately in the target situation in which they need the language they are learning. The second reason for pre-experience learners is to study EGBP to be well prepared for future professional life. The third and most important difference is that pre-experience learners' courses prepare for examinations, which dictates a specific content of syllabus while teaching.

\section{English for Specific Business Purposes (ESBP)}

ESBP refers to the courses that target "jobexperienced learners who bring business knowledge and skills to the language learning situation" (Dudley-Evans and St John, 1998, p. 55). Courses are tailor-made and taken from the business context of learners to meet their specific needs. They focus on specific language skills and specific communicative events to enable learners to gain some practical experience to communicate jobrelated matters and issues. In this context, St. John (1996) explains that business executives "do not want to be transported back to a typical classroom" (p. 14), for course books are "intended for pre-experience students and not for the executive" (p. 13). For Instance, competencies such as being able to understand other managers from foreign countries and correspondence in English are accentuated over other ones (St. John, 1996).

\section{NEEDS ANALYSIS}

Historically, the term 'analysis of needs' first appeared in India in 1920 (West, 1997). Needs analysis
(NA) was introduced to language teaching through the movement of ESP (Richard, 2001). It refers to "the process of determining the needs for which a learner or group of learners require a language and arranging the needs according to priorities" (Richards and Schmidt, 2010, p. 389).

ELT syllabus designers adopt two types of needs analysis: learner analysis and task analysis (Nunan, ,1988). As to learner analysis, it is built around information about learners' and aims to specify their motivation for learning the language. Results of such an analysis help select the content of the syllabus and place learners together. Such data help teachers update or modify the syllabus or methodology to detect areas of possible conflict within a teaching programme. In this case, data analysis focuses more on the reasons for which learners learn the language and on the classroom activities they have a penchant for. Regarding task analysis, it categorises the language skills needed to perform life-like communicative tasks. What characterises this type of analysis is that it often comes after learner analysis process that sets up the communicative aims learners desire (Nunan, , 1988)

\section{Needs Analysis in ESP}

With reference to ESP, Dudley Evans and St. John (1998) maintain that NA is the core of ESP classes, which leads to very specific course components. Hutchinson and Waters (1987) also describe needs analysis as the distinctive feature of ESP integral to the making of every ESP course and a prerequisite to determine the specific reasons for learning the language. By the same token, Bastrukmen (2010) wrote:

Needs analysis in ESP refers to a course development process. In this process the language and skills that the learners will use in their target professional or vocational workplace or in their study areas are identified and considered in relation to the present state of knowledge of the learners, their perceptions of their needs and the practical possibilities and constraints of the teaching context. The information obtained from this process is used in determining and refining the content and method of the ESP course. (p.19)

Richard (2001) contends that "from the 1960s, the demand for specialized language programs grew and applied linguists increasingly began to employ needs analysis procedure in language teaching" (p.51). Brindley (as cited in Richard, 2001) explains that by the 1980s, 
needs-based philosophy appeared in language teaching, especially with the emergence of ESP. NA is either minimal, made up of a series of concise questions to provide teachers and trainers with an idea about the needs of learners, or sizeable for a thorough diagnosis of more needs (Frendo, 2005). Mackay and Mountford (1978) also state that teaching ESP courses effectively and designing them appropriately, entails examining the rational for the language use. Bouzidi (2009) maintains that NA "describes the entire context in which English is used, including the skills, setting, topics, and relevant language functions" (p.11).

\section{Types of Needs in ESP Classes}

Richards (2001) describes needs as "the difference between what learners can presently do in a language and what they should be able to do" (p.54). Hutchinson and Waters (1987) classify needs in ESP into target needs and learning needs. Target needs refer to the necessities, lacks, and wants of the learner. First, necessities relate to the sort of needs identified by the demand of the target situations, i.e. what learners need to know in order to behave adequately in the target situation. Second, lacks are simply the necessities learners require. Finally, wants involve what learners seek to obtain from the language course. Additionally, Dudley-Evans and St. John (1998, p.123) categorise needs into a) objective and perceived needs, b) subject and felt needs, product oriented needs, and c) process oriented needs. To explicate, objective and perceived needs are those that enable learners to follow instructions accurately and which teachers can get from facts. Subject and felt needs refer to the ones that correspond to cognitive and affective needs derived from learners and which help them feel confident. Product-oriented needs relate to the needs elicited from the target situation (TS), whereas the process-oriented needs refer to the needs taken from the learning situation (LS) (Dudley-Evans and St. John, 1998).

\section{Needs Analysis in Business English Classes}

NA is believed to play a pivotal role in BE more than English for other specific purposes, mainly owing to the various needs of learners and the less predictable spectrum of skills as well as language (Dudley-Evans and St. John, 1998). Frendo ( 2005) argues that NA in BE “ is not an objective exercise; it entails exercising judgment and finding compromises to make the best use of resources in a particular teaching context. It is about working with learners to decide on the best way forward" (p.16). Brieger (1997) maintains that needs analysis in BE determines and takes account of the general language knowledge (general vocabulary), specialist language knowledge (specific vocabulary of a professional domain), and the general and professional communication skills needed in the real world.

\section{Types of Needs in Business English Classes}

With reference to needs in business English, Frendo (2005) differentiates between learners' perceived needs and felt needs. Learners' perceived needs refer to the needs picked out by teachers, sponsors, and coworkers, whose experience in the field enables them to perform such a task. To elucidate, learners' perceived needs center on what students should be able to do by the end of a lesson. The felt needs are simply those representing the learners' viewpoint, i.e. what they aim at studying or improving (Donna, 2000). In this context, Frendo (2005) illustrates:

Understanding business needs is of critical importance. A provider of language training must consider the needs of the sponsor, who may be a company, or a head of department, or the HR (Human Resources) manager. These will all have certain perspectives on what the learners will need to cover on a course. It is important to make it clear to sponsors that their needs are recognized and will be addressed, while remaining realistic about what is promised. (p.26)

In simpler terms, NA is an integral part of ESP teaching. It refers to the process carried out by teachers, course designers, and trainers to collect information about learners to discover and identify the needs around which a course or a syllabus will be built or designed. It is therefore the bridge that joins the point of departure (current situation) with its end (target situation) (DudleyEvans and St. John, 1998). NA emphasises defining learners' learning needs, their wants, wishes, and desires. It caters for learners' needs and objectives, communicative use of language, and how well they can read, write, speak, or understand that language (proficiency). In other words, NA highlights the requirements and expectations of the target environment where ESP teachers measure the constraints as well as the possibilities of teaching, adopting effective methods and strategies and assuming different roles to reach the objectives of their courses.

\section{THE ROLE OF THE ESP TEACHER (PRACTITIONER)}

Beyond a shadow of doubt, ESP classes cannot meet their objectives without a proficient ESP teacher 
(Breiger, 1997; Dudley-Evans and St. John, 1998; Ellis and Johnson, 2004; Donna, 2000). Dudley-Evans and St. John (1998) and Swales (1985) preferred the term 'the ESP practitioner'. The main reason behind a term such as this is their conviction that the function of ESP teachers is not solely limited to teaching, but it extends to include other roles. The role of an ESP practitioner goes beyond that of an ordinary teacher. Significant is the difference between teaching ESP and English for general purposes (EGP), for instance. It is a common belief among ELT theoreticians that EGP teachers cannot teach ESP effectively as they lack the necessary training to teach such a discipline (Ouakrim, 1997). Such a claim prevails among ESP practitioners due to the big difference in practicing both arts (Hutchinson and Waters, 1987).

To further explicate, the way the purpose of learning the target language is defined and the manner in which ESP instructions are implemented distinguish ESP from EGP in general (Ennaji,1997). To draw a clear line between ESP and EGP, Hutchinson and Waters (1987) state that "in theory nothing, in practice a great deal" ( $p$. 53). The reason is that specific purpose and special language are two strikingly different notions (Mackay and Mountford, 1978). With this in mind, teaching ESP necessitates "methodologies that are specialized or unique" (M. Johns and Dudley-Evans, 199, p.305), which raises the question of the role of teachers within such a discipline. According to Dudley-Evans and St. John (1998), ESP practitioners perform the role of a course designer and material provider, a researcher, a collaborator, an evaluator and a teacher.

\section{The ESP Practitioner as a Course Designer and Material Provider}

As textbooks may sometimes fail to meet the course objectives and fulfil learners' needs, ESP practitioners sometimes deem it necessary to design their own activities to attain their objectives. Thus, ESP practitioners, based on needs analysis, devise customised materials that better link the objectives of lessons with the needs of learners (Hutchinson and Waters, 1987; Ennaji, 1997; M. Johns and Dudley-Evans, 1991; Basturkmen, 2010). In other words, the role of ESP teachers as providers of tailor-made materials is to choose and adapt them when there is "a mismatch between the content of ESP textbooks and actual workplace language demands" (Bouzidi, 2009, p.10).

\section{The ESP Practitioner as a Researcher}

As researchers, ESP practitioners have to conduct research studies in the field to vary their teaching styles and methods (Dudley-Evans and St. John, 1998). They should always update their knowledge to go hand in hand with economic, scientific, and technological changes to prepare students for the challenges of today's world (Ennaji, 1997) and engage their interest in the subject taught. In other words, by matching research findings to the learning and teaching environment, .i.e. by making needs of students the starting point of every ESP lesson, courses will be more fruitful and purposeful, and classes will be more dynamic (Hutchinson and Waters, 1987).

\section{The ESP Practitioner as a Collaborator}

The role of the ESP practitioner as collaborator involves cooperating with the subject specialists (DudleyEvans and St. John, 1998). On one level, this requires a sense of cooperation in eliciting information about the subject students are to carry out in their professional environment to achieve integrating specialist studies, language, and activities. On another level, specialists may give their point of view concerning the teaching material the teacher has designed. The complete form of such a collaboration will culminate in the emergence of teamteach classes in which both teachers and business trainers cooperate to teach the skills and language of communication (Hutchinson and Waters, 1987).

\section{The ESP Practitioner as an Evaluator}

Evaluation is another vital task ESP practitioners are to perform (Dudley-Evans and St. John, 1998). Evaluation includes testing students and assessing courses and teaching materials. Testing students serves the purpose of evaluating their competence in terms of possessing the necessary language and skills to start a certain academic course or job. The second purpose is to have insights into how much they have learnt from a course. Besides, the process of evaluating ESP teaching materials necessitates that practitioners seek to measure the effectiveness of the material employed and the extent to which such a material meets the learners' expectations (Hutchinson and Waters, 1987).

Unlike EGP classrooms, wherein the teacher is the centre of knowledge, ESP classes are different as students may know more than teachers. Students contribute to the enrichment of the course thanks to their job experience that they bring to and make use of in the classroom. Effective use of such an advantage by the teacher would render classes an environment conducive for genuine communication, for instance (Dudley-Evans and St. John, 1998). Put differently, ESP teachers guide and enable students to internalise their communicative practices with their objectives. Tasks such as these require being a flexible teacher and a good listener who cares about and caters for what intrigues students, especially in BE classes (Frendo, 2005; Breiger, 1997). 


\section{THE ROLE OF BUSINESS ENGLISH TEACHER}

The above mentioned roles of ESP practitioners are not the sole performed ones. Various are the tasks they are to assume according to the needs and specificities of each domain. To fathom such a point, ESP practitioners in the business field are to carry out extra roles because of the learner's specific needs. In this perspective, understanding the business needs and environment is extremely imperative to setting and achieving the goals of BE learners practitioners are to act accordingly (Ellis and Johnson, 1994; Breiger, 1997, Donna, 2000). Put succinctly, like any other ESP course, in order for a business course to meet the learners' needs, it should cater for their prior goals according to their business function. On that account, to meet the requirements of their clients and learners, teachers of $\mathrm{BE}$ need to play additional and different roles in addition to the tasks of ESP practitioners listed above (Frendo, 2005).

\section{Business English Teacher as a Trainer}

A significant difference in approach exists between a teacher and a trainer. Whilst a teacher is traditionally considered as an educator whose task is to instruct, educate, and teach learners to enable them to be soaked in their life, a trainer is a person whose main role is to change a person's behaviour or ability to enable them to perform specific tasks or do particular jobs successfully (Frendo, 2005). A teacher as trainer in this context refers to $\mathrm{BE}$ teachers working in training organisations where they offer customised training programmes intended for particular participants for a short period. In this case, content specialist of business course is not a prerequisite to becoming a trainer, yet being au fait with the learner's field is the most important. Such familiarity can be employed as a vehicle to ensure effective teaching (Ellis and Johnson, 1994). To exemplify, whereas training is 'job-oriented', teaching is 'person-oriented' (Briedger, 1997). That is to say, if language teachers help students learn a language for various purposes; a trainer trains them to behave adequately - both linguistically and pragmatically.

\section{Business English Teacher as a Coach}

A coach refers to a person who assists learners to exploit the job-related learning opportunities in their own field. Such a role focuses on helping learners to thoroughly identify their own strengths and weaknesses and plan accordingly (Frendo, 2005). Autonomy development then is the chief goal of the coach's job. Succinctly put, the main role of a coach is to help learners become autonomous via taking full responsibility for their own learning.

\section{Business English Teacher as a Consultant}

A consultant is an expert who has got enough expertise in a job or a domain (Frendo, 2005). In the field of business English, a lot of self-employed/freelance teachers work as consultants, for such a job ensures gaining access to potential clients (Briedger, 1997). Thanks to the business acumen they have developed in through teaching business, teachers/consultants provide expertise, design or run a training programme, discuss contracts, do needs analysis, and assess training delivery and results. Expertise may also include the ability to analyse communication needs, suggest a training provider, or choose the most conducive location for a course. (Frendo, 2005; Briedger, 1997).

\section{CONCLUSION}

ESP is a manifold field complex to teach, especially when teachers are not well trained to act as teachers, material designers, evaluators, coaches, researchers, and collaborators, etc. Therefore, to guarantee effective learning and teaching and provide the push and motivation to excel, teachers are pedagogically required to exhibit a reasonable level of competence to succeed in such a job. When teaching ESP, practitioners, especially business English teachers, should make informed decisions about what, why, who, and how they teach. They also need a bunch of qualities such as credibility, a professional spirit, and knowledge about the discipline they are going to teach. Hence, they should demonstrate a tendency towards learning since learners often know a lot about their professional field. Business English teachers should adapt themselves to different teaching situations and contexts to obtain satisfactory results; they must have high training skills, deep knowledge and understanding of the function of English in business communication, and insight into business learners' needs, expectations, and learning strategies. Besides, business English teachers are required to be knowledgeable about personal as well as interpersonal interaction in different cultural contexts; they are required to have solid and updated business background to help their learners achieve adequate communicative competence.

\section{REFERENCES}

[1] Basturkmen, Helen. (2010). Developing Courses in English for Specific Purposes. Basingstoke, England : Macmillan.

[2] Brieger, N. (1997). Teaching Business English Handbook. York, England: York Associates. 
[3] Bouzidi, H. (2009). Between the ESP classroom and the workplace: Bridging the gap. English Teaching Forum, 4 7(3), 10-17.

[4] Donna. Sylvie, (2000). Teach Business English. Cambridge, United Kingdom: Cambridge University Press.

[5] Dudley-Evans, T., \& St John, M. J. (1998). Developments in English for specific purposes. Cambridge, United Kingdom: Cambridge University Press.

[6] Ellis, Mark.,\& JOHNSON, Christine. (1994). Teaching business English. Oxford, England: Oxford University Press.

[7] Ennaji. Moha, (1997). «The ESP teacher in the private and public sectors ». In ELHADDAD El Mostapha, NAJBI Mohamed, GUELZIM Rachida, AIT ALI Ayoub, LARBI Imad(Eds.), ESP in the Arab world: Reality check and prospects:Proceedings of the XVII th MATE Annual Conference (p.19-22). Erfoud: Moroccan Association of Teachers of English.

[8] Frendo, E. 2005. How to teach business English. Harlow, England: Pearson Education Limited.

[9] Hutchinson, T. \& Waters, A. (1987). English for specific purposes. Cambridge, United Kingdom: Cambridge University Press.

[10] Johns, A. M. \& Dudley-Evans, T. (1991) 'English for Specific Purposes: International in Scope Specific in Purpose', Teaching English to Speakers of Other Languages Quarterly, 25, 297-314.

[11] Kachru, Y. \& Nelson, C. L. (2006) World Englishes in Asian Contexts. Aberdeen, Hong Kong: Hong Kong University Press.

[12] Mackay, R., \&Mountford, A. (Ed.). (1978). English for specific purposes. London, England: Longman.

[13] Nelson, C. L. (2011). Intelligibility and world Englishes. New York, NY: Routledge.

[14] Nunan, D. (1988). Syllabus design. Oxford, England: Oxford University Press.

[15] Ouakrim. Mohamed, (1997). «Perceptions and reality: Demystifying ESP». In ELHADDAD El Mostapha, NAJBI Mohamed, GUELZIM Rachida, AIT ALI Ayoub, LARBI Imad(Eds.), ESP in the Arab world: Reality check and prospects:Proceedings of the XVII th MATE Annual Conference (pp.19-22). Erfoud: Moroccan Association of Teachers of English.

[16] Richards, J. C. (2001). Curriculum Development in Language Teaching. Cambridge, United Kingdom: Cambridge University Press.

[17] Richards, J. C., \& Schmidt, R. (2010). Longman dictionary of language teaching and applied
linguistics.Harlow, England: Pearson Education Limited.

[18] Robinson, P. (1991). ESP today: A practitioner's guide. New York, NY: Prentice Hall.

[19] St John, M. J. (1996). Business is booming: business English in the 1990s. English for Specific Purposes, 15, 3-18.

[20] Strevens, P. (1988). ESP after twenty years: A reappraisal. In M. Tickoo (Ed.), ESP: State of the art (pp. 1-13). Singapore: SEAMEO Regional Centre.

[21] Swales, J. (1985). Episodes in ESP. Oxford: Pergamon.

[22] West, R. (1997). Needs analysis: State of the art. In R. Howard \& G. Brown (Eds.), Teacher education for LSP (pp. 68-79). Clevedon: MultilingualMatters. 